\title{
A Kinetic Study of the Non-enzymatic Browning Reaction Between Histamine and Glucose
}

\author{
Munehiko Tanaka,* Yuji Nagashima, ${ }^{*}$ and Takeshi Taguchi* \\ (Accepted January 21, 1986)
}

\begin{abstract}
The model system containing histamine, glucose and microcrystalline cellulose was used to investigate the non-enzymatic browning reaction. The kinetics of the brown pigment formation and loss of histamine were studied as a function of heating temperature, $\mathrm{pH}$ and water activity of the systems. The rates of the brown pigment formation and the histamine loss followed zero order after an initial induction period and first order kinetics of up to a loss of at least $50 \%$ level, respectively. These rates increased with increasing temperature and $\mathrm{pH}$, and decreasing water activity. The activation energies of both reactions were in the range of $23-24 \mathrm{kcal} / \mathrm{mol}$ for the pigment production, $17-21 \mathrm{kcal} / \mathrm{mol}$ for the histamine loss. It was suggested that the content of histamine can be reduced by controlling the condition of the model systems before brown discoloration becomes appreciable.
\end{abstract}

Some food poisoning outbreaks resulting from the consumption of fresh and processed fish have been reported to be caused by high levels of histamine in the implicated products. ${ }^{1,2)}$ This type of food poisoning is generally called scombroid poisoning because of its frequent association with the Scombroidae family of fish such as mackerel, skipjack tuna, yellowfin tuna and albacore. ${ }^{3-5 \text { ) }}$

Although the numerous studies on the formation and accumulation of histamine in fish have been carried out in connection with fish freshness, ${ }^{8-{ }^{8)}}$ there is limited literature available concerning the changes in histamine level during heatprocessing and storage of fish products from the standpoint of the chemical reaction kinetics. Since histamine is a basic amine, it should undergo the non-enzymatic browning reaction (the Maillard reaction) in the presence of reducing sugars. As a result, the histamine level is supposed to decrease during processing and storage.

In this study, the participation of histamine in the non-enzymatic browning reaction in a model system under steady state conditions of temperature, $\mathrm{pH}$ and water activity was examined to elucidate the kinetic behaviour of histamine during heat-processing.

\section{Materials and Methods}

\section{Preparation of the Model Systems}

In order to facilitate the collection of non- enzymatic browning data, model systems were used. The model systems studied consisted of histamine dihydrochloride (Wako Pure Chemical Industries, Co.), glucose (Kokusan Kagaku, Co.) and microcrystalline cellulose (Avicel, Asahi Kasei, Co.). Microcrystalline cellulose is inert to the browning reaction and serves as a solid support for the model system. A molar histamine-glucose ratio of 1:3 was employed in all the experiments. Histamine dihydrochloride $(92 \mathrm{mg})$ and glucose $(270 \mathrm{mg}$ ) were dissolved in $150 \mathrm{ml}$ of $0.1 \mathrm{M}$ phosphate buffer solution ( $\mathrm{pH} \mathrm{6,7,} \mathrm{or} \mathrm{8).} \mathrm{Then}$ microcrystalline cellulose powder $(50 \mathrm{~g})$ was slurried with this buffer solution. The samples were frozen in a blast freezer $\left(-30^{\circ} \mathrm{C}\right)$ and then freeze dried. After freeze drying, the samples were crushed with a mortar and pestle to a fine powder and then equilibrated to the desired water activity in vacuo over an appropriate saturated salt solution. For the preparation of saturated salt solutions, $\mathrm{MgCl}_{2}$ (Aw 0.33), $\mathrm{Mg}\left(\mathrm{NO}_{3}\right)_{2}$ (Aw 0.51 ), and $\mathrm{KCl}(\mathrm{Aw} 0.84)$ were used. The samples were allowed to equilibrate for 3-5 days at room temperature until the proper water activity was obtained. The freeze dried sample per se had a water activity of 0.14 . The water activity of the sample was checked with a Shibaura AW meter WA-351 (Shibaura Denshi, Co.).

\section{Heat Processing}

These samples were heated under conditions as

* Department of Food Engineering and Technology, Tokyo University of Fisheries, 4-5-7 Konan, Minato, Tokyo 108, Japan (田中宗彦, 長島裕二, 田口 武: 東京水産大学 食品工学科). 
described below:

pH level: $\mathrm{pH} 6,7,8$

Water activity: $\quad 0.14,0.33,0.51,0.84$

Heating temperature and heating time:

$80^{\circ} \mathrm{C} ; 40,80,120,180 \mathrm{~min}$

$100^{\circ} \mathrm{C} ; 15,30,45,60 \mathrm{~min}$

$120^{\circ} \mathrm{C} ; 5,10,15,20 \mathrm{~min}$

For heating purposes, $1 \mathrm{~g}$ of the sample was placed in a vial $(1.0 \mathrm{~cm}$ i.d. $\times 4.2 \mathrm{~cm})$ and hermetically sealed with a screw cap to minimize heat transfer limitations in come-up time. At $80^{\circ} \mathrm{C}$ and $100^{\circ} \mathrm{C}$, the samples were heated in a water bath, and at $120^{\circ} \mathrm{C}$ in a fluidized silica sand bath. At each sample time, the samples were quickly placed into an ice bath.

\section{Chemical Analyses}

The non-enzymatic browning reaction was monitored by measuring brown pigment formation and loss of histamine. The development of brown pigment was determined as absorbance at $420 \mathrm{~nm}$ on a Hitachi spectrophotometer Model 101 after the heated sample $(100 \mathrm{mg})$ was incubated with $10 \mathrm{ml}$ of $0.1 \mathrm{M}$ Tris buffer $(\mathrm{pH} 7.0)$ at $40^{\circ} \mathrm{C}$ for $2 \mathrm{~h}$. The amount of brown pigment formed was expressed as absorbance at $420 \mathrm{~nm}$ per g solid. Histamine was separated by Amberlite CG-50 (type 1) column chromatography as described by Kawabata et $a l^{10)}$ and its content was measured using the diazo reagent prepared according to Grundemeier and Andrew. ${ }^{11}$ All analyses were made in duplicates.

\section{Results and Discussion}

\section{Rate of Brown Pigment Formation}

Fig. 1 presents the typical representative pattern of brown pigment formation as a function of heating time, temperature and water activity at pH 7. All samples except heating at $120^{\circ} \mathrm{C}$ showed an induction period and then increased linearly with time for each condition. This is similar to that reported by Lea and Hannan ${ }^{12)}$ and Warmbier et al. ${ }^{13)}$ It is presumed that colorless browning intermediates are being produced during the initial induction period. The constant rate of brown pigment formation is indicative of a zero order reaction.

The rate constant ( $\Delta \mathrm{Abs} . / \mathrm{g}$ solid $\cdot \mathrm{min}) \mathrm{cal}$ culated from the slopes of the linear portion of the pigment formation curves are given in Table 1. The rate of brown pigment formation of each system increased as the heating temperature became higher. The rate of brown pigment formation was also controlled by $\mathrm{pH}$ and water activity of the model systems. The influences of $\mathrm{pH}$ and

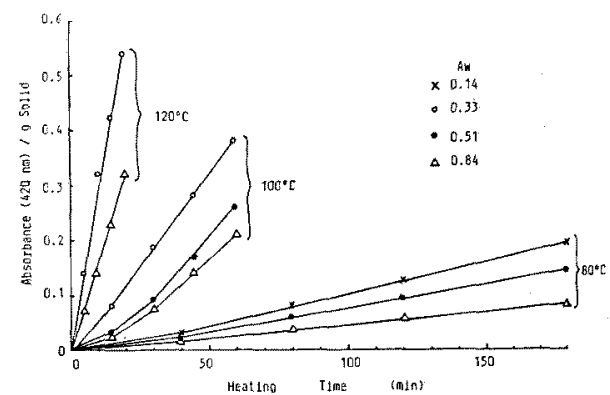

Fig. 1. The typical representative pattern of brown pigment formation as a function of heating time, temperature and water activity at $\mathrm{pH} 7$. The amount of brown pigment produced is expressed as absorbance at $420 \mathrm{~nm}$ per $\mathrm{g}$ solid.

Table 1. Rate constants and activation energies for brown pigment formation

\begin{tabular}{|c|c|c|c|c|c|}
\hline \multirow{2}{*}{$\mathrm{pH}$} & \multirow{2}{*}{ Aw } & \multicolumn{3}{|c|}{$\mathbf{k}(\triangle \mathrm{Abs} / \mathrm{g}$ solid $\cdot \mathrm{min})$} & \multirow{2}{*}{$\underset{(\mathrm{kcal} / \mathrm{mol})}{\mathrm{E}^{*}}$} \\
\hline & & $80^{\circ} \mathrm{C}$ & $100^{\circ} \mathrm{C}$ & $120^{\circ} \mathrm{C}$ & \\
\hline \multirow{5}{*}{6.0} & 0.14 & $7.20 \times 10^{-4}$ & $4.33 \times 10^{-3}$ & $2.20 \times 10^{-2}$ & 23.4 \\
\hline & 0.33 & $7.78 \times 10^{-4}$ & $3.67 \times 10^{-3}$ & $1.93 \times 10^{-2}$ & 23.2 \\
\hline & 0.51 & $4.44 \times 10^{-4}$ & $3.33 \times 10^{-3}$ & $1.53 \times 10^{-2}$ & 24.2 \\
\hline & 0.84 & $3.33 \times 10^{-4}$ & $1.83 \times 10^{-3}$ & $9.33 \times 10^{-3}$ & 22.8 \\
\hline & 0.14 & $1.06 \times 10^{-3}$ & $6.67 \times 10^{-3}$ & $3.33 \times 10^{-2}$ & 23.6 \\
\hline \multirow[t]{4}{*}{7.0} & 0.33 & $1.08 \times 10^{-3}$ & $6.22 \times 10^{-3}$ & $3.20 \times 10^{-2}$ & 23.2 \\
\hline & 0.51 & $7.50 \times 10^{-4}$ & $3.78 \times 10^{-3}$ & $2.33 \times 10^{-2}$ & 23.5 \\
\hline & 0.48 & $5.00 \times 10^{-4}$ & $3.33 \times 10^{-3}$ & $1.45 \times 10^{-2}$ & 23.1 \\
\hline & 0.14 & $1.58 \times 10^{-3}$ & $7.90 \times 10^{-3}$ & $4.40 \times 10^{-2}$ & 22.7 \\
\hline \multirow[t]{3}{*}{8.0} & 0.33 & $1.12 \times 10^{-3}$ & $6.26 \times 10^{-3}$ & $3.86 \times 10^{-2}$ & 24.2 \\
\hline & 0.51 & $7.90 \times 10^{-4}$ & $3.95 \times 10^{-3}$ & $2.64 \times 10^{-2}$ & 24.0 \\
\hline & 0.84 & $5.41 \times 10^{-4}$ & $2.69 \times 10^{-3}$ & $1.58 \times 10^{-2}$ & 23.1 \\
\hline
\end{tabular}

* Activation energies (E) are calculated from the reaction rate constants using the Arrhenius equation. 
water activity on the rate of brown pigment production are further illustrated in Fig. 2. The browning rate was found to increase with $\mathrm{pH}$ of the system, but the pronounced effect of $\mathrm{pH}$ on browning was observed especially at elevated temperature and lower water activity conditions. The browning rate decreased as water activity increased; this is unlike that found in most solid systems which show a maximum rate near Aw $0.6-0.8 .^{13)}$

The activation energies for brown pigment formation are tabulated in Table 1. It can be seen that activation energies are in the range of 23-24 $\mathrm{kcal} / \mathrm{mol}$ in all the model systems tested in this study. These values are in the same range for the browning reaction as reported by Warmbier et al. ${ }^{14)}$

\section{Rate of Histamine Loss}

The typical representative pattern of histamine loss at pH 7 as a function of heating time, tem-

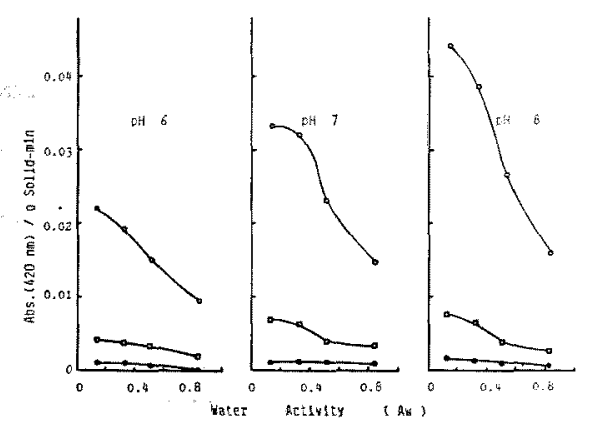

Fig. 2. Effects of heating temperature, $\mathrm{pH}$ and water activity on the rate of brown pigment formation. $\mathrm{O}-\mathrm{O}: 120^{\circ} \mathrm{C}, \square-\square: 100^{\circ} \mathrm{C}, \longrightarrow: 80^{\circ} \mathrm{C}$. perature and water activity is depicted in Fig. 3 on a semi-log plot. An induction period was not observed for histamine loss or at least it was not detected within the accuracy of the determinations used in this study. It is apparent from this Figure that the initial condensation reaction of histamine with glucose is first order for up to at least $50 \%$ loss, not zero order as the brown pigment formation follows. This observation is quite similar to the finding of Warmbier et al. ${ }^{13,14)}$ It is noteworthy that a significant amount of histamine was destroyed even before the formation of brown pigment became appreciable. This has serious implications from the standpoint of processing of food contaminated with histamine, because histamine content would be reduced before the color of food becomes objectionably brown.

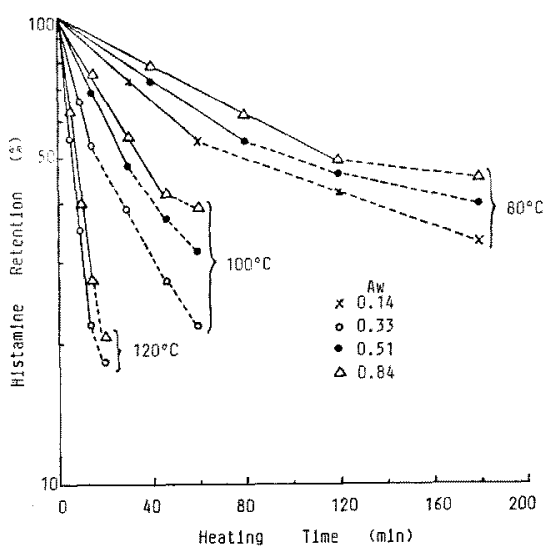

Fig. 3. The typical representative pattern of histamine loss as a function of heating time, temperature and water activity at $\mathrm{pH} 7$.

Table 2. Rate constants and activation energies for histamine loss

\begin{tabular}{cccccc}
\hline \multirow{2}{*}{$\mathrm{pH}$} & $\mathrm{Aw}$ & \multicolumn{3}{c}{$\mathrm{k}\left(\mathrm{min}^{-1}\right)$} & \multirow{2}{*}{$\begin{array}{c}\mathrm{E}^{*} \\
\text { (kcal/mol) }\end{array}$} \\
\cline { 3 - 5 } & & $80^{\circ} \mathrm{C}$ & $100^{\circ} \mathrm{C}$ & $120^{\circ} \mathrm{C}$ & 18.2 \\
6.0 & 0.14 & $6.95 \times 10^{-3}$ & $2.72 \times 10^{-2}$ & $9.98 \times 10^{-2}$ & 17.7 \\
& 0.33 & $4.46 \times 10^{-3}$ & $1.94 \times 10^{-2}$ & $5.91 \times 10^{-2}$ & 17.4 \\
& 0.51 & $3.78 \times 10^{-3}$ & $1.34 \times 10^{-2}$ & $4.82 \times 10^{-2}$ & 17.2 \\
7.0 & 0.84 & $3.31 \times 10^{-3}$ & $1.15 \times 10^{-2}$ & $4.05 \times 10^{-2}$ & 18.2 \\
& 0.14 & $1.10 \times 10^{-2}$ & $4.10 \times 10^{-2}$ & $1.56 \times 10^{-1}$ & 19.8 \\
& 0.33 & $6.60 \times 10^{-3}$ & $2.88 \times 10^{-2}$ & $1.19 \times 10^{-1}$ & 19.3 \\
& 0.51 & $6.16 \times 10^{-3}$ & $2.52 \times 10^{-2}$ & $1.00 \times 10^{-1}$ & 19.8 \\
& 0.84 & $5.15 \times 10^{-3}$ & $1.94 \times 10^{-2}$ & $8.60 \times 10^{-1}$ & 21.3 \\
& 0.14 & $1.67 \times 10^{-2}$ & $7.08 \times 10^{-2}$ & $3.01 \times 10^{-1}$ & 20.3 \\
& 0.33 & $1.21 \times 10^{-2}$ & $6.00 \times 10^{-2}$ & $2.73 \times 10^{-1}$ & 21.7 \\
\hline
\end{tabular}

- Activation energies (E) are calculated from the reaction rate constants using the Arrhenius equation. 


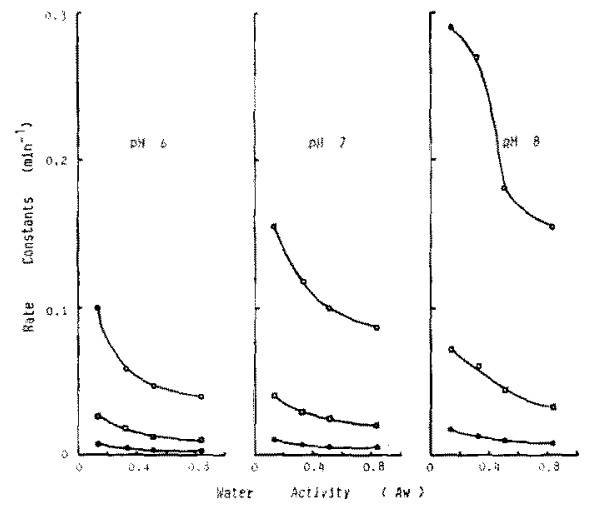

Fig. 4. Influences of heating temperature, $\mathrm{pH}$ and water activity on the rate of histamine loss. $\bigcirc-0: 120^{\circ} \mathrm{C},[]-[]: 100^{\circ} \mathrm{C},-80^{\circ} \mathrm{C}$.

The histamine loss rate constants $\left(\mathrm{min}^{-1}\right)$ for each system are given in Table 2 . The rate constants were calculated from the slopes of the linear portion of the histamine loss curves. It is obvious from this Table that histamine loss rates increased with increasing heating temperature. The rate of histamine loss due to the non-enzymatic browning reaction with glucose was also influenced by $\mathrm{pH}$ and water activity of the systems. The calculated rate constants are plotted against water activity of the model systems at the three pH levels (Fig. 4). The rate of histamine loss increased with increasing $\mathrm{pH}$; this may be attributed to the fact that increasing the $\mathrm{pH}$ increases the reactivity of histamine due to the acidbase equilibrium. The effect of water activity on the histamine loss rate was more striking at the lower water activity region, especially at the higher heating temperature. As a whole, the influences of $\mathrm{pH}$ and water activity on the histamine loss rate were found out to be fairly similar to those on the rate of the brown pigment formation in the same model systems.

The activation energy for histamine loss was shown in Table 2. Activation energies are in the range of $17-21 \mathrm{kcal} / \mathrm{mol}$ irrespective of water activity at the given pH. These values are slightly lower than those for the brown pigment formation given in Table 1. It seems that in histamineglucose system the reaction of histamine loss is faster than that of brown pigment formation.
There was a slight tendency that the activation energy increased at higher $\mathrm{pH}$, but the significance of this difference in the activation energy due to $\mathrm{pH}$ is obscure.

The accelerated browning reaction data ob. L tained in this study might be applicable to the processing of fish products contaminated with histamine such as dried fish, canned fish meat and fish meal. Two significant and practical conclusions can be drawn from this work. First, histamine undergoes the non-enzymatic browning reaction in the presence of glucose and as a consequence its content is reduced. Second, the formation of brown pigment can be inhibited by shifting the water activity to higher and $\mathrm{pH}$ to lower. So that it would be possible to reduce histamine content before marked development of brown color in products by controlling the heating temperature, $\mathrm{pH}$ and water activity.

\section{References}

1) E. Geiger: Science, 121, 865-866 (1955),

2) M. H. Merson, W. B. Baine, E. J. Gangarosa, and R. C. Swanson: J. Amer. Med. Assoc., 228, 1268-1269 (1974).

3) Y. Omura, R.J. Price, and H.S. Olcott: J. Food Sci., 43, 1779-1781 (1978).

4) S. L. Taylor, L. S. Guthertz, M. Letherwood, and E. R. Lieber: Appl. Environ. Microbiol, 37, 274-278 (1979).

5) E. T. Ryser, E. H. Marth, and S. L. Taylor: $J$. Food Prot., 47, 378-380 (1984).

6) T. Dabrowski, E. Kolakowski, and K. Markiewicz: Nahrung, 12, 631-637 (1968).

7) M. Takagi, A. Iida, and S. Oka: Bull. Japan. Soc. Sci. Fish., 37, 1079-1083 (1971).

8) W. J. Edmund and R. R. Eitenmiller: J. Food Sct., 40, 516-519 (1975).

9) H. Yamanaka, K. Shiomi, T. Kikuchi, and $M$. Okuzumi: Bull. Japan. Soc. Sci. Fish., 50, 695701 (1984).

10) T. Kawabata, Y. Uchida, and T. Akano: Bull. Japan. Soc. Sci. Fish., 26, 1183-1191 (1960).

11) E. W. Grundemeier and A. C. Andrews: Trans. Kansas Acad. Sci., 68, 62-64 (1965).

12) C. H. Lea and R. S. Hannan: Biochim. Biophys. Acta, 3, 313-325 (1949).

13) H. C. Warmbier, R. A. Schnickels, and T.P. Labuza: J. Food Sci., 41, 528-531 (1976).

14) H. C. Warmbier, R. A. Schnickels, and T.P. Labuza: I. Food Sci., 41, 981-983 (1976). 